\title{
The Influence of Selected Personal and Professional Demographic Characteristics on the Income Level of Private Farmers in the Ukraine
}

\author{
Jeantyl Norze ${ }^{1,}$ *, Viacheslav Leonidovich Sereda ${ }^{2}$, Michael Fletcher Burnett ${ }^{1}$ \\ ${ }^{1}$ Department of Agricultural and Extension Education and Evaluation, Louisiana State University, Baton Rouge, United States \\ ${ }^{2}$ Louisiana Board of Ethics, Baton Rouge, United States
}

\author{
Email address: \\ jnorze1@1su.edu (J. Norze), slava.sereda@LA.GOV (V. L. Sereda), vocbur@1su.edu (M. F. Burnett) \\ *Corresponding author
}

\section{To cite this article:}

Jeantyl Norze, Viacheslav Leonidovich Sereda, Michael Fletcher Burnett. The Influence of Selected Personal and Professional Demographic Characteristics on the Income Level of Private Farmers in the Ukraine. International Journal of Applied Agricultural Sciences.

Vol. 5, No. 4, 2019, pp. 98-104. doi: 10.11648/j.ijaas.20190504.14

Received: May 21, 2019; Accepted: August 19, 2019; Published: September 4, 2019

\begin{abstract}
The primary purpose of this study was to determine the influence of selected demographic characteristics and animal production measures on the income of private farmers in the Ukraine. A proportional random sample was drawn from the three Oblasts selected for inclusion in the study based on the total number of private farmers in the accessible population. This sample included 250 farmers from each of the two larger Oblasts and 150 from the smaller Oblast. These farmers were selected for personal interviews by raion specialists. A survey was designed to collect necessary information. Raion specialists received a one-day training session to learn personal interview techniques. Most of the farmers, $(83.4 \%)$ had a degree of technical college or above, and the average age of farmers was 45.8. Swine was the animal commodity that was included on the largest number of private farms (33.5\%), and milk cows accounted for the largest portion of the farmers' annual income (4089.94 Hryvnia - Z). Three factors contributed significantly to a model explaining the total income of private farmers in the Ukraine. These factors included Milk Cow production, Swine production, and Educational level of the farmer. Further research is needed to examine the animal production on a broader scale particularly in the other regions of the country and with emphasis on the economies of size in the different animal commodities. Given the importance of the educational level in total income of farmers, programs should be designed to enable farmers to pursue higher levels of education.
\end{abstract}

Keywords: Farming, Livestock Production, Ukraine, Farming Income, Privatization

\section{Introduction}

After the breakup of the Soviet Union, the newly independent Eastern European countries were placed in the position that they had to adjust to free market rules. One of the areas where this adjustment was most critical was agriculture. Therefore, the Ukraine began efforts designed to make the critical reforms in agriculture. According to the United Nation Land Administration Guidelines [1], one of the first and most important steps in the transition from a central governmentally controlled system of agriculture to a market economy is the establishment of private ownership of land. Prior to 1992, all agricultural lands (except for small household plots) in the Ukraine had belonged to the government in the form of state and collective farms. In 1991, the Ukrainian Parliament adopted the Land Code Decree referred to as "About Land Reforms." That was the beginning of land reforms in the Ukraine. In October 2001, the Ukrainian Parliament adopted a new Land Code which provides the "Right to Land" in Chapter III, Article 78 [2]. This Article indicated that land in the Ukraine can be in private, communal and state ownership. Over eight million hectares of land were privatized, with plots averaging five hectares.

Through this land reform in the agricultural sector, the land that had previously been in state and collective farms was divided among the people who had previously worked for/on the state and collective farms. Each of these 
individuals received a portion of the land for their personal ownership. In addition, the agricultural equipment that had been used on the state/collective farms was divided among the former workers. This equipment had previously belonged to the government. These people had a choice to use their newly acquired land in essentially one of two ways. They could either lease their land to someone else that wanted to farm the land or they could become private farmers. Most of the people had very limited experience regarding how to produce agricultural products. Virtually all of this experience had been on their home plots which meant that it was only on a very small scale. For many of the former farm workers, this limited experience made their decision about whether or not to become a farmer very easy. They did not feel prepared to face the different challenges associated with moving from being a small scale producer into being a farmer on a much larger scale. This situation led the Ukraine to a long-term agricultural crisis [3]. The agricultural sector had failed to adapt to the country's new economic reality [3]. There was a lack of coherent vision for the agricultural reform following the country's independence [3].

Agricultural reforms are usually difficult [3]. People may resist change even when there is dissatisfaction because change is uncertain and requires an individual to let go something familiar and predictable for something unfamiliar and unpredictable [4]. Uncertainty often creates fear and resistance. In addition, individuals are more concerned about what they may lose than what they may gain [5]. "Antecedent conditions shape the present and the emergent future" [6]. The inheritance of an old system can affect the rate and the pace of the change [7]. According to Roger's theory of diffusion of innovation, adoption of new ideas, behaviors or products does not occur simultaneously [8]. However, information has the power to accelerate the rate and the pace of the adoption process. Education and/or training programs are key drivers of change and innovation. Individuals' commitment and self-efficacy, which are prerequisites for change, depend on competences provided by education and training [9]. A clear vision and strategy are necessary to lead the change [10].

Previously, collective farms used a centralized decisionmaking structure which removed agricultural producers from the decision making position on the farm. However, after new farmers received their agricultural land and were faced with farm operational and decision-making challenges, it became necessary to establish farmers educational programs similar to outreach programs in the U.S. extension service and also to determine major factors that would influence farmers' productivity.

A three-year extension education project intended to improve agricultural production of small private farmers in three oblasts-Cherkasy, Khmelnytsky, and Vinnytsya-in Ukraine was established. It was funded by the US Agency for International Development (USAID), the Louisiana State University Agricultural Center (LSU AgCenter), as Project contractor, partnered with the World Laboratory, Ukraine Branch, Kiev and state agricultural universities/academies in the three oblasts to organize, plan, conduct, and evaluate education programs targeting private farmers.

Organized through a state agricultural university/academy in each oblast, the Project covered 67 raions (counties) and involved approximately 3,500 private farmers. Selected university/academy faculty possessing advanced degrees in different agricultural disciplines and raion specialists (county agents) with a basic agricultural degree were recruited and trained in extension program development and adult education methods. At the end of the Project evaluation data was collected to describe farmers "profile and to measure the impact of educational programs on Ukrainian farmers" productivity.

\section{Purpose and Objectives}

The primary purpose of this study was to determine the influence of selected demographic characteristics and animal production measures on the income of private farmers in the Ukraine. The following specific objectives were developed to guide the research:

1. Describe private farmers in selected oblasts of the Ukraine on the following demographic characteristics:
a) Age;
b) Gender;
c) Education level.

2. Describe private farmers in selected oblasts of the Ukraine on the following selected animal production characteristics:
a) Milk cow;
b) Beef cow;
c) Swine;
d) Chicken;
e) Geese;
f) Duck;
g) Horse;
h) Eggs.

3. Describe private farmers in selected oblasts of the Ukraine on animal income from each commodity and total income.

4. Determine if relationships exist between total income and the following measures:

a) Selected demographic
1. Age;
2. Gender;
3. Education level.

b) Animal production
1. Milk cow;
2. Beef cow;
3. Swine;
4. Chicken;
5. Geese;
6. Duck;
7. Horse;
8. Eggs.

5. Determine if a model exists explaining a significant portion of the variance in total income of private farmers in selected oblasts of the Ukraine from the following selected demographic and animal production 
measures:

a) Selected demographic

1. Age;

2. Gender;

3. Education level.

b) Animal production

1. Milk cow;

2. Beef cow;

3. Swine;

4. Chicken;

5. Geese;

6. Duck;

7. Horse;

8. Eggs.

\section{Methods}

\subsection{Population and Sample}

The target population for the study was defined as private farmers in the Ukraine. The accessible population included private farmers in three selected oblasts in the Ukraine. The sample consisted of registered private farmers in the three oblasts selected for inclusion in the study. A total of 250 farmers were randomly selected in two of the oblasts and 150 in the other (based on the oblast population size) for personal interviews by the raion specialists. Lists of the populations of registered private farmers in the three oblasts were obtained from the respective oblast authorities. There were 1,$128 ; 1,038$; and 652 registered private farmers in the three oblasts included in the study. Random samples were drawn from these lists using a computerized random numbers table. Primary and alternate lists of sample members were prepared. If a farmer on the primary list refused to be interviewed or could not be found after two attempts by the raion specialist the next name on the alternate list was chosen.

\subsection{Instrumentation}

To collect the data for this study, a survey was designed based on the literature, and the survey was validated by a panel of experts. The survey was designed to collect information about Ukrainian farmers' personal attributes, their agricultural operations, including production, marketing of livestock products, and participation in and perception of the extension project. Measurements regarding the extension project were done using yes or no responses and Likert-type scales.

\subsection{Data Collection}

Data collection was initially conducted in the late summer. All data collection was completed by the end of September. Raion specialists took part in a one-day training session to learn personal interview techniques, become familiar with the survey instruments, and practice interviewing. In the practice session, each raion specialist interviewed a fellow raion specialist to get the experience of a real-life encounter.

Information gathered in the surveys was entered into an
Access database and analyzed for entry errors. After a thorough data cleaning process was completed, data were exported from Access and imported in the SPSS statistical software for data analysis.

\section{Findings and Results}

\subsection{Objective One}

The Ukrainian farmers who participated in the study were described on the following demographic characteristics: age, gender, and educational level to meet the objective one analysis.

\subsubsection{Age}

The age of participants is presented in Table 1. Among the 658 Ukrainian farmers who responded to the survey, 655 (99.5\%) provided information about their age. The farmers whose age fell in the age group of 41-45 years old represented the highest percentage $(19.7 \%)$ of the respondents and those whose age fell into the age group of 66 years old or greater represented the lowest percentage (3.2\%). The mean age of the Ukrainian farmers of the study was $45.76(S D=10.06)$ years old. The age of the Ukrainian farmers ranged from 23 to 80 years old.

Table 1. Age of the Ukrainian Farmers in the Study.

\begin{tabular}{lll}
\hline Age Group & N & Valid Percentage \\
\hline 30 or Less & 51 & 7.8 \\
$31-35$ & 56 & 8.5 \\
$36-40$ & 86 & 13.1 \\
\hline & & \\
\hline Age Group & $\mathbf{N}$ & Valid Percentage \\
\hline $41-45$ & 219 & 19.7 \\
$46-50$ & 119 & 18.2 \\
$51-55$ & 106 & 16.2 \\
$56-60$ & 63 & 9.6 \\
$61-65$ & 24 & 3.7 \\
66 or Greater & 21 & 3.2 \\
Total & 658 & 100 \\
\hline
\end{tabular}

Note. Age ranged from 23 to $80, M=45.76, S D=10.06$.

\subsubsection{Gender}

Gender is another variable on which the Ukrainian farmers in the study were described. Of the 658 Ukrainian farmers who participated in the study, $594(90.3 \%)$ identified themselves as males and only $64(9.7 \%)$ identified themselves as females.

\subsubsection{Educational Level}

The level of education of the Ukrainian farmers who participated in the study were also described (see Table 2). Of the 658 Ukrainian farmers in the study, 655 (99.5\%) conveyed information about their level of education. Among those who responded, $341(52.1 \%)$ had a college degree and $201(30.7 \%)$ had technical college degree together representing the largest number of participants in the study. Those who only spent 8 years in school or earned a $\mathrm{PhD}$ were the two groups reported by the lowest percentage $(.3 \%)$ in 
each group.

Table 2. Level of Education of the Ukrainian Farmers in the Study.

\begin{tabular}{lll}
\hline Level of Education & n & Percentage \\
\hline 8 Years of School & 2 & .3 \\
High School & 44 & 6.7 \\
Vocational Education & 60 & 9.2 \\
Technical College Degree & 201 & 30.7 \\
College Degree & 341 & 52.1 \\
Master Degree & 5 & .8 \\
PhD & 2 & .3 \\
Total & 658 & 100 \\
\hline
\end{tabular}

Note. $\mathrm{n}=658$.

\subsection{Objective Two}

Descriptive analyses were performed on Ukrainian animal production and livestock income.

\section{Ukrainian Animal Production}

Data regarding livestock production of the participants in the study is presented in Table 3. The animal produced by the target group of participants was swine $(33.5 \%)$. The mean number of swine produced by these individuals was 16.58 $(S D=66)$. The production ranged from 1 to 800 head of swine. In contrast, only nine percent of the farmers produced rabbits. The rabbit production had a mean of $27(\mathrm{SD}=20.71)$ and ranged from 10-80 head.

\subsection{Objective Three}

The livestock income of the Ukrainian farmers in Ukrainian currency unit--Ukraine Hryvnia $(Z)$ is summarized in Table 4. As illustrated, the category of livestock that account for the largest source of animal income among the Ukrainian farmers was milk cow. The Ukrainian.

Table 3. Percentage of Animal Production among the Ukrainian Farmers in the Study.

\begin{tabular}{llllll}
\hline Animal & Number of farmers & \% of farmers & Mean Head & SD & Range \\
\hline Swine & 217 & 33.50 & 16.58 & 66.00 & $1-800$ \\
Dairy Cow & 156 & 24.00 & 10.53 & 53.07 & $1-540$ \\
Chicken & 126 & 19.60 & 33.74 & 18 & 78.85 \\
Beef Cow & 86 & 13.40 & 10.70 & 53.84 & 134.67 \\
Geese & 69 & 10.70 & 28.55 & 26.01 & $1-690$ \\
Duck & 69 & 2.13 & 13.93 & $5-1000$ \\
Horse & 14 & 1.40 & 27.00 & $8-200$ \\
Rabbits & 9 & & $30-5000$ & 20.71 \\
\hline
\end{tabular}

Note. $n=658$.

Table 4. Farmers' Income from Livestock in Ukraine Hryvnia (Z).

\begin{tabular}{llll}
\hline Animal & Mean Income & SD & Range \\
\hline Dairy Cow & 4089.94 & 18207.05 & $118.20-178718.40$ \\
Beef Cow & 2539.14 & 8276.25 & $122-58804$ \\
Horse & 1963.93 & 3880.29 & $90-15000$ \\
Swine & 1642.45 & 6917.07 & $21.93-87720$ \\
Geese & 323.78 & 937.72 & $33-6050$ \\
Eggs & 202.95 & 134.22 & $15-900$ \\
Chicken & 113.32 & 91.49 & $13-650$ \\
Duck & 87.50 & 108.97 & $16.50-770$ \\
Total & 4891.84 & 23304.77 & $15-307918.4$ \\
\hline
\end{tabular}

Note. Range of Livestock Income $=₹ 15$ to $₹$ 307918.4.

Farmers earned on average $z$ z $4089.94(S D=18207.05)$ annually from dairy cow alone. The dairy cow income ranged from $z 118.20$ to $z 178718.40$. Whereas ducks provided the lowest amount of income to Ukrainian farmers. The mean income of the farmers from broilers was only $z 113.32(S D=$ 91.49). The income from ducks ranged from $z 16.50$ to $z 770$. In total, livestock produced an average income of $z 4891.84$ $(S D=23304.77)$. The Ukrainian livestock income ranged from $z 15$ to $z$ 307918.4. In addition, the Ukrainian farmers who participated in the study earned a total income of $z$ $49535.49(S D=166693.05)$ on average. Their total income ranged from $z 233.92$ to $z 2641800$.

\subsection{Objective Four}

For the purpose of objective four analysis, relationships were examined between participants' total livestock income and selected demographic variables and selected animal production measures.

\subsubsection{Relationships Between Total Livestock Income and Demographic Variables}

When relationships between the total livestock income and the selected demographic characteristics were examined, only educational level was found to be significantly related 
(see Table 5). The level of education of the Ukrainian farmers was found to have a positive, significant relationship with the livestock total income, $r h o(633)=.091, p<.05$.

Table 5. Relationships between total livestock income and the selected demographics of the Ukrainian Farmers.

\begin{tabular}{llll}
\hline Variables & $\boldsymbol{R}$ & $\boldsymbol{N}$ & $\boldsymbol{p}$ \\
\hline Education level & .091 & 633 & .011 \\
Age & .036 & 633 & .184 \\
Gender & -.029 & 633 & .230 \\
\hline
\end{tabular}

\subsubsection{Relationships Between Total Livestock Income and Animal Production}

Table 6. Relationships between total income and animal production among the Ukrainian farmers.

\begin{tabular}{lll}
\hline Variable & $\boldsymbol{R}$ & $\boldsymbol{p}$ \\
\hline Dairy Cow & .616 & $<.001$ \\
Swine & .596 & $<.001$ \\
Beef Cow & .354 & $<.001$ \\
Geese & .054 & .086 \\
Duck & .049 & .107 \\
Chicken & -.048 & .115 \\
Rabbits & -.025 & .265 \\
Horse & -.003 & .467 \\
\hline
\end{tabular}

Note. $n=633$.

Relationships were also examined between total livestock income and production levels of selected animal commodities (see Table 6). Examination of the table revealed that livestock total income had strong, positive relationships with dairy cow, $r(639)=.616, p<.01$, and swine production, $r(639)=.596, p<.001$, and moderate, positive relationships with beef cow, $r(639)=.354, p<.001$.

\subsection{Objective Five}

Multiple Regression Analysis (MRA) was used to determine if a model exists explaining a significant portion of the variance in the total income of private farmers in the selected oblasts of Ukraine with total income as the dependent variable and selected demographics and production measures as independent variables.

Prior to conducting the MRA, the researchers examined the Tolerance Values to check for multi-collinearity. The analysis indicated no excessive multi-collinearity. Examination of the multiple regression analysis presented in Table 7 revealed that at step one, the dairy cow production variable contributed significantly to the regression model, $F(1,631)=385.149, p$ $<.001$, and accounted for $37.9 \%$ of the variation in total income. Adding the swine production variable to the regression model explained an additional $3.2 \%$ of the variation in total income and this change in $R^{2}$ was significant, $F(1,630)$ $=34.77, p<.001$. Adding another variable, the educational level of the farmers, to the regression model explained an additional $0.5 \%$ of the total variation in the total income with a subsequent significant change in $R^{2}, F(1,629)=165.683, p<$ 0.05 . Overall, the three variable model explained $41.6 \%$ of the variance in the total income of the Ukrainian private farmers in the study.

The nature of the influence of these variables was such that higher dairy cow production, higher swine production, and a higher education level were associated with higher levels of total income.

Table 7. Multiple Regression of Ukrainian farmers' total income, selected animal production, and selected demographics from three oblast of Ukraine.

\begin{tabular}{llllll}
\hline Source of Variation & Sum of Squares & df & Mean Square & F & P \\
\hline Regression & $7.386 \mathrm{E}+12$ & 3 & $2.462 \mathrm{E}+12$ & 149.861 & $<.001$ \\
Residual & $1.033 \mathrm{E}+13$ & 629 & $1.643 \mathrm{E}+10$ & & \\
Total & $1.772 \mathrm{E}+13$ & 632 & & & \\
\hline
\end{tabular}

\begin{tabular}{lllllllll}
\hline Model Summary & & & & & & & \\
\hline Model & R & R Square & R Square Change & F Change & df1 & df2 & Sig. F Change & Standardized Coefficients Beta \\
\hline Dairy Cow & .616 & .379 & .379 & 385.149 & 1 & 631 & $<.001$ & .376 \\
Swine & .641 & .412 & .032 & 34.770 & 1 & 630 & $<.001$ & .300 \\
Education & .646 & .417 & .005 & 5.738 & 1 & 629 & .017 & .073 \\
Level & .67 & & & & & \\
\hline
\end{tabular}

\begin{tabular}{lll}
\hline Variables not in the Equation & & \\
\hline Variables & $\boldsymbol{t}$ & $\boldsymbol{p}$ \\
\hline Duck & -1.632 & .103 \\
Beef Cow & -1.556 & .120 \\
Chicken & -1.195 & .232 \\
Geese & -.929 & .353 \\
Age & .852 & .394 \\
Rabbit & -.839 & .402 \\
Breeding Swine & .812 & .417 \\
Gender & -.569 & .570 \\
Horse & -.556 & .578 \\
\hline
\end{tabular}




\section{Discussions}

The findings suggest that the Ukrainian farmers who participated in the study were relatively young. They were younger than their European and American counterparts. Almost $60 \%$ of farmers in Europe are between 40 and 64 years old [11]. The mean age of the farmers in the U.S. has increased from 50.5 years to 58.3 years old, during the past 30 years [12]. The Ukrainian farmers in the study were also highly educated. In contrast, a very low percentage of farmers in Europe and the U.S. attains a high level of education. Only $8.9 \%$ of Europeans working in agriculture have a high level of educational attainment [11]. In the U.S., only $19 \%$ of the rural adults has a college degree [13]. The results also suggest that farming in Ukraine is a male dominated field with men representing the highest percentage of the farmers participating in the study. Similar studies have found that men in Europe and the U.S. are more likely to be the owners of the farms $[14,12]$. In Europe, women account for $35.1 \%$ of the agricultural labor force [11]. In the U.S., women represent $30 \%$ of the farmers [12]. In addition, production data indicated that the dominant livestock production in Ukraine was swine with the highest numbers of livestock producers belonging to the "swine producers" category while dairy cows represented their major source of livestock income. This may be explained by several factors. First, swine are easier to handle than cows. Second, they grow and develop much faster. Third, they have a shorter breeding cycle with a higher conception rate, and are multiparous. Nonetheless, dairy cows were more costeffective. They can be kept for a longer period of time producing milk. Lastly, looking at the regression analysis findings, dairy cows, swine, and level of education were the three major contributing factors of the total livestock income of the Ukrainian farmers in the study. These factors established significant, positive relationships with the total income variable indicating the higher production of dairy cows and swine and the higher education level were associated with higher levels of total income of the farmers.

The findings of this study are promising taking into account the decline of profitability of livestock enterprises in Ukraine since the collapse of the Soviet Union in 1991. Large agricultural enterprises in Ukraine were unable to maintain livestock operations due to management and feed supply inefficiency [15]. Although Ukrainian farmers focused on new technology in some areas, they did not focus on the basics of crop and livestock management, according to Durst as cited in Battel [16]. Consequently, the demand for beef and pork in Ukraine was satisfied mostly by private producers and household farms [15].

In addition, the impact of education on agricultural productivity of farmers has been well documented. The results of this study suggested that education level impacts positively the gross income of the Ukrainian farmers. However, Wordofa and Sassi [17] who studied the impact of farmers' training center on household income in Ethiopia found no significant effect of training on livestock income.
Lack of skills, knowledge, and adequate technologies constrain livestock productivity, especially small and medium scale production systems [18].

\section{Conclusions}

The findings of the study indicate that private farmers in Ukraine are highly educated middle-age adults. The findings also suggest that the gender gap in farming remains an issue in Ukraine. Men make up more than $90 \%$ of the private farmers in the study. Their main animal production is swine. However, their main source of income is dairy cows. Lastly, the results of the regression analysis indicate that only dairy cows, swine, and level of education influence significantly the total livestock income of the private farmers in the study.

\section{Implications and Recommendations}

The Ukrainian farmers in the study were middle-age adults. Having young Ukrainian adults interested in farming is crucial to ensure livestock production and its economic value in the future. The aging farmer population across the world remains a concern especially in Europe. It is crucial to attract individuals with younger demographics towards farming if the Ukrainian governments want to maintain or increase livestock production in the future. Activities such as funding, training, coaching should be made available to young people who want to start a farming business. However, the existing gender gap in farming in Ukraine may hinder women's ability to achieve gender equality. Closing the gender gap could help the country achieve agricultural development and food security. Farming in Ukraine could benefit from increasing participation of women and young adults in the agricultural workforce since livestock production impacts significantly the farmers' gross income. The researchers recommend that future studies examine the impact of the Ukrainian extension service on livestock income. This research was conducted in three different Oblasts located in the central part of Ukraine. Additional studies need to be conducted with the complete population of Ukrainian farmers, specifically from west and east parts of the country. Further research needs to be done with more detailed information about inputs or with a sample of farmers with narrow livestock production to be able to determine the (optimum) economies of size in livestock production. The Ukrainian government should encourage more farmers to produce livestock by establishing programs to help them to invest in livestock facilities and provide assistance in purchasing of young livestock. This may help change farming in Ukraine mostly on a personal scale to reach a level of commercial production.

\section{References}

[1] United Nations. (1996). Land Administration Guidelines with Special Reference to countries in Transition. Retrieved from http://www.unece.org/fileadmin/DAM/hlm/documents/Publica tions/land.administration.guidelines.e.pdf. 
[2] Bondar, A., \& Lilje, B. (2002). Land Privatization in Ukraine. Retrieved from https://www.fig.net/pub/fig_2002/Ts76/TS7_6_bondar_lilje.pdf.

[3] Sarna, A. (2014). The transformation of agriculture in Ukraine: From collective farms to agroholdings. Centre for Eastern Studies, 127.

[4] Swanson, R. A., \& Holton, E. F. (2001). Foundations of Human Resource Development. San Francisco: BerrettKoehler, Inc.

[5] Rousseau, D. M. (1996). Changing the Deal while Keeping the People. Academy of Management Executive.

[6] Pettigrew, A. M. (1990). Longitudinal field research on change: theory and practice. Organization science. Vol. 1, No. 3.

[7] Pettigrew, A. M., Hendry, C., and Sparrow, P. R. (1989). Training in Britain: Employers' Perspectives on Human Resources, London: Her Majesties Stationery Office.

[8] Rogers, E. M. (2003). Diffusion of Innovation (5th ed.). New York: A Division of Simon \& Schuster, Inc.

[9] Jacobs, R. L. (2002). Institutionalizing organizational change through cascade training. Journal of European Industrial Training. Vol. 26, No. 2/3/4, pp. 177-182. https://doi.org/10.1108/03090590210422058.

[10] Kotter, J. (2012). The 8-Step Process for Leading Change. Retrieved from Kotter International: C: $\mathrm{IU}$ http://www.kotterinternational.com/the-8-step-process-forleading-change.

[11] Eurostat (2017). Farmers in the EU - statistics. Retrieved from https://ec.europa.eu/eurostat/statisticsexplained/index.php/Farmers in the EU - statistics.
[12] USDA - NASS, Census of Agriculture (2012). Farm Demographics - U.S. Farmers by Gender, Age, Race, Ethnicity, and More. Retrieved from https://www.agcensus.usda.gov/Publications/2012/Online_Res ources/Highlights/Farm_Demographics/.

[13] USDA's Economic Research Service (2015). Educational attainment increasing in rural America, Retrieved from https://www.farmprogress.com/education/usda-erseducational-attainment-increasing-ruralamerica?ag_brand=farmfutures.com.

[14] EU Agricultural Economic Briefs (June, 2012). Women in EU Agriculture And Rural Areas: Hard Work, Low Profile. Retrieved from https://ec.europa.eu/agriculture/sites/agriculture/files/ruralarea-economics/briefs/pdf/07_en.pdf.

[15] World Data Center (2015). For geoinformatics and sustainable development. Retrieved from http://wdc.org.ua/en/node/29.

[16] Battel, A. (2017). Can Ukraine regain its reputation as the breadbasket? Improving dairy cattle efficiency on former collective farms in Ukraine. Retrieved from https://www.canr.msu.edu/news/can-ukraine-regain-itsreputation-as-the-breadbasket-improving-dairy-cattleefficiency-on-former-collective-farms-in-ukraine.

[17] Wordofa, M. G. \& Sassi, M. (2017). Impact of Farmers' Training Centres on Household Income: Evidence from Propensity Score Matching in Eastern Ethiopia. Social Sciences. Vol. 7, No. 4.

[18] FAO. (2019). Animal Production and Health. Retrieved from http://www.fao.org/ag/againfo/themes/en/animal_production.h tml. 